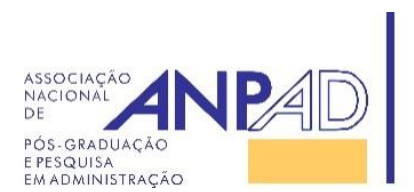

Disponível em

http://www.anpad.org.br/rac

RAC, Rio de Janeiro, v. 20, n. 6, art. 6, pp. 753-776, Nov./Dez. 2016

http://dx.doi.org/10.1590/1982-7849rac2016160116

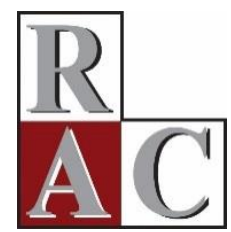

\title{
Using Voter-choice Modeling to Plan Final Campaigns in Runoff Elections
}

Wagner Antonio Kamakura ${ }^{1}$

Rice University ${ }^{1}$

Artigo recebido em 13.05.2016. Última versão recebida em 21.06.2016. Aprovado em 11.07.2016. Publicado online em 16.09.2016. 


\title{
Resumo
}

Embora a eleição em dois estágios seja a forma mais comum de eleição presidencial no mundo, o comportamento do eleitor no pleito em dois estágios ainda não recebeu uma atenção condizente à que merece na literatura. Eleições em dois estágios ou turnos oferecem, aos consultores políticos e aos candidatos, dados ricos e factuais sobre a preferência do eleitor, revelada através do comportamento deste observado no primeiro turno, que pode guiar o planejamento e a implementação da campanha final. Essas eleições em dois turnos também permitem que analistas políticos apliquem seus modelos de escolha eleitoral ao comportamento real (ao invés da intenção) de voto numa eleição multipartidária, e validem suas previsões na eleição bipartidária do segundo turno. Nesse estudo, utilizo os resultados das quatro eleições presidenciais mais recentes no Brasil para demonstrar como modelos de escolha do eleitor podem ser aplicados para guiar a campanha política em eleições de dois turnos.

Palavras-chave: marketing político; eleições em dois estágios; eleições multipartidárias; modelo logit anidado; heterogeneidade latente.

\begin{abstract}
Even though runoff elections are the most common form of presidential elections in the world, voter-choice behavior in these two-round elections have not received the attention they deserve in the literature. Two-round elections provide political consultants and candidates with rich and factual data on voter preferences, revealed through the voting behavior observed in the first round, which can guide the planning and implementation of their final campaign. They also allow political analysts to apply their voter-choice models to actual voting behavior (rather than voting intentions) in a multi-party election during the first round, and validate their predictions in a two-party election in the final round. I use results from the four most recent Brazilian presidential elections to demonstrate how voter-choice models can be applied to guide political campaigns in runoff elections.
\end{abstract}

Key words: political marketing; runoff elections; multi-party elections; nested-logit; unobserved heterogeneity. 


\section{Introduction}

Two-stage or runoff elections are the most prevalent voting system for electing a president in modern democracies (Golder, 2005). Out of 109 countries where presidents are democratically elected, 71 use a two-stage or runoff voting system (ACE, n.d.); they are also the prevalent electoral system in Latin America (Pérez-Linãn, 2006). These two-stage elections offer an opportunity for politicians to plan their final campaign using analytical methods based on actual voting data, because they can rely on the actual voting observed in the first-stage election to learn about voter perceptions and preferences before the final election.

The insights gained from the first round can be used in many ways. First, and foremost, they show the specific voting districts where the surviving candidates occupy a strong or weak position. Second, they show the political capital held by eliminated candidates, and the value and feasibility of their support in the final campaign. Third, the results from the first round indicate the specific voting districts where the support of an eliminated candidate would be of greatest value for the short campaign before the final voting. Fourth, these first-round results can be combined with polls gathered before the second round, to produce more precise simulations for the final outcome.

Planning and executing a political campaign for the second round in two-stage elections is quite distinct from the campaign in the first round because, after the first round, candidates have factual information on voters' preferences at the electoral-district level. Rather than relying solely on stated preferences and intentions gathered from opinion polls, surviving candidates can plan and implement their final campaign based on revealed preferences, implicit in the actual voting observed in each electoral district. In other words, in the final campaign, candidates can rely on factual information on what voters have done, rather than relying solely on what they say they would do. Political polls are notoriously inaccurate in Brazil; one of the better-known pollsters (Datafolha) correctly predicted the winner in the first and second rounds in 2014, but with considerable errors in the actual percentage of votes, as shown in Table 1, which compares the actual vote counts against reported voter intentions.

Table 1

Voter Intentions Gathered Via Opinion Polls Before the First and Second Rounds of the 2014 Presidential Elections in Brazil

\begin{tabular}{lccccc}
\hline & Date & $\begin{array}{c}\text { Dilma } \\
(\mathrm{PT})\end{array}$ & $\begin{array}{c}\text { Aécio } \\
(\mathrm{PSDB})\end{array}$ & $\begin{array}{c}\text { Marina } \\
\text { (PSB) }\end{array}$ & Abstentions* \\
\hline First Round - Actual & $\mathbf{5 - O c t}$ & $\mathbf{3 0 . 3 \%}$ & $\mathbf{2 4 . 4 \%}$ & $\mathbf{1 5 . 5 \%}$ & $\mathbf{2 7 . 2 \%}$ \\
\hline \multirow{2}{*}{ Voter intention } & 4-Oct & $40 \%$ & $24 \%$ & $22 \%$ & $14 \%$ \\
\cline { 2 - 6 } & 2-Oct & $40 \%$ & $21 \%$ & $24 \%$ & $15 \%$ \\
\cline { 2 - 6 } & $26-S e p$ & $40 \%$ & $18 \%$ & $27 \%$ & $15 \%$ \\
\hline
\end{tabular}

Continues 
Table 1 (continued)

\begin{tabular}{lccccc}
\hline & Date & $\begin{array}{c}\text { Dilma } \\
(\mathrm{PT})\end{array}$ & $\begin{array}{c}\text { Aécio } \\
(\mathrm{PSDB})\end{array}$ & $\begin{array}{c}\text { Marina } \\
(\mathrm{PSB})\end{array}$ & Abstentions* \\
\hline Second Round - Actual & $\mathbf{2 6 - O c t}$ & $\mathbf{3 8 . 2 \%}$ & $\mathbf{3 1 . 9 \%}$ & - & $\mathbf{3 0 . 0 \%}$ \\
\hline \multirow{3}{*}{ Voter intention } & $25-$-Oct & $47 \%$ & $42 \%$ & -- & $11 \%$ \\
\cline { 2 - 6 } & $22-$-Oct & $47 \%$ & $43 \%$ & -- & $10 \%$ \\
\cline { 2 - 6 } & $16-$-Oct & $43 \%$ & $45 \%$ & -- & $12 \%$ \\
\hline
\end{tabular}

Note. Source: Instituto de Pesquisa Datafolha. (2014, September 19). Brasil eleições 2014, intenções de votos para presidência $\begin{array}{llllll}d a & \text { República } & \text { (Relatório } & \mathrm{n}^{\circ} & \text { PO813761). } & \text { Retrieved }\end{array}$ http://media.folha.uol.com.br/datafolha/2014/09/19/intencao_de_voto_presidente.pdf; Instituto de Pesquisa Datafolha. (2014, September 26). Brasil eleições 2014, intenções de votos para presidência da República (Relatório $\mathrm{n}^{\circ}$ PO813763). Retrieved from http://media.folha.uol.com.br/datafolha/2014/09/27/intencaodevotoeavaliacaopresidente.pdf; Instituto de Pesquisa Datafolha. (2014, October 4). Brasil eleições 2014, intenções de votos para presidência da República (Relatório ${ }^{\circ}$ PO813765). Retrieved from http://media.folha.uol.com.br/datafolha/2014/10/04/intencao_de_voto_presidente.pdf; Instituto de Pesquisa Datafolha. (2014, October 16). Brasil eleições 2014, intenções de votos para presidência da República- $2^{\circ}$ turno (Relatório $n^{\circ}$ PO813773). Retrieved from http://media.folha.uol.com.br/datafolha/2014/10/15/intencao-de-voto-presidente-2-turno.pdf; Instituto de Pesquisa Datafolha. (2014, October 22). Brasil eleições 2014, intenções de votos para presidência da República $\begin{array}{llllll} & 0 & \text { (Relatório } & \mathrm{n}^{\circ} & \text { PO813775). } & \text { Retrieved }\end{array}$ http://media.folha.uol.com.br/datafolha/2014/10/22/intencao_de_voto_presidente_2_turno.pdf; Instituto de Pesquisa Datafolha. (2014 October 24). Brasil eleições 2014, intenções de votos para presidência da República - $2^{\circ}$ turno (Relatório ${ }^{\circ}$ PO813776). Retrieved

http://media.folha.uol.com.br/datafolha/2014/10/25/intencao_de_voto_presidente_vespera_2_turno.pdf

* Abstentions also include undecided voters in opinion polls

Aside from being unreliable as shown in Table 1, stated preferences gathered by opinion polls do not offer the same level of granularity afforded by preferences revealed by actual vote counts in the first round. I demonstrate that the results from the first round represent a treasure trove of information for the political scientist and marketer because of their objectivity and the level of detail they provide about voter preferences.

The main purpose of this study is to demonstrate how voter-choice models can be applied to help politicians (both eliminated and surviving candidates from the first stage) plan the campaign before the final election. For this purpose, I use the results from the past four presidential elections in Brazil, with a more in-depth analysis of the most recent one (2014). First, I apply a first-order Markov model (Brown \& Payne, 1986; Hillygus, 2005; McCarthy \& Ryan, 1977) to the results from three past presidential elections, to understand how voting behavior shifts from the first to the second round. This analysis shows that, across the three elections, voters tend to maintain their vote between the two rounds, if their chosen alternative is still available. This indicates that surviving candidates must focus primarily on winning votes from the candidates who were eliminated in the first round, rather than spending their limited resources and time defending their base or poaching from the competitor. I then apply the Kamakura and Mazzon (2007) latent-factor nested logit model of voter choice to the data from the first round of the most recent (2014) presidential election, to illustrate how the candidates (the winner and runner up, as well as the eliminated ones) can use the insights gained from the first round to plan the final campaign. Finally, I use the results from the second stage to validate the policy simulations performed right after the first round.

\section{The Dynamics of Vote Transfers in Two-Stage Elections: A Markov Perspective}

Given that my primary goal is to demonstrate how the modeling of voter choice observed in the first stage can be used to plan the final campaign, it will be helpful to understand how voters shift their choices between the two stages. Except for the possibility of unforeseen strategic behavior, it would seem rational that voters for the winner and runner-up maintain their choices in the second stage. After 
all, they have already made the decision to support the candidate after a long political campaign, and there is limited additional information to be acquired in the much shorter period prior to the final vote. Similarly, one would expect that voters who abstained in the first round (when there was a broader range of political positions to choose from) would also abstain from selecting among a more restricted set in the second round.

Fortunately, I have data from three prior elections in Brazil (the largest democracy in the world, in population of eligible voters, where presidents are elected in absolute-majority runoff elections) from which we can learn about how voters shift their choices between the two rounds. For this purpose, I estimate a first-order Markov model (Brown \& Payne, 1986; Hillygus, 2005; McCarthy \& Ryan, 1977) describing the transition of votes among the options available in the two stages. I define the Markov model as,

$$
\boldsymbol{S}_{i}=\boldsymbol{M} \boldsymbol{F}_{i} ; i=1, \ldots, N
$$

where:

- 3-dimensional vector containing the vote count in district $i$ for the two candidates competing in the second round, and the number of abstentions.

- $\quad(\mathrm{K}+1)$-dimensional vector containing the vote count in district $i$ for the $\mathrm{K}$ candidates competing in the first round, and the number of abstentions.

- $3 \mathrm{X}(\mathrm{K}+1)$ Markov transition matrix with elements, assumed to be constant across all districts $0 \leq$ $m_{i j} \leq 1$ and $\sum_{i=1}^{3} m_{i j}=1 ; j=1, K+1$.

Estimation of the Markov transition matrices $M$ across the $N$ electoral districts in Brazil in 2002, 2006 and 2010 led to the results shown in Table 2. As shown in Table 2, despite the large number of districts $(\mathrm{N}=6,159, \mathrm{~N}=2,980$ and $\mathrm{N}=5,719$ in 2002, 2006 and 2010, respectively), the Markov matrices explain the transition of votes from first to second round exceptionally well ( $\mathrm{R}$-square $=0.98,0.98$ and 0.99 , respectively), despite the assumption of a homogeneous transition matrix across districts (Brown $\&$ Payne, 1986). Note however, that the assumption of a homogeneous transition matrix does not imply homogeneity in voter preferences, because the expected transitions are conditional on preferences revealed in the first round. Given the quality of fit with the simple, homogeneous Markov model, there is limited room for improvement with a more complex ecological-inference model. Most importantly, these transition matrices provide valuable insights about what happens between the first and second rounds.

Table 2

Estimated Markov Transition Matrix for the Brazilian Presidential Elections

\begin{tabular}{lcccccccc}
\hline 2002 & & \multicolumn{3}{c}{ From first round } & & & & \\
\cline { 3 - 9 } & & Abstention & $\begin{array}{c}\text { Lula } \\
(\mathrm{PT})\end{array}$ & $\begin{array}{c}\text { José Serra } \\
\text { (PSDB) }\end{array}$ & Garotinho & $\begin{array}{c}\text { Ciro } \\
\text { Gomes }\end{array}$ & Others & $\begin{array}{c}\text { Votes } \\
(\mathrm{MM})\end{array}$ \\
\hline To second \\
round & Abstention & $84 \%$ & $0 \%$ & $0 \%$ & $20 \%$ & $16 \%$ & $0 \%$ & 29.1 \\
& Lula (PT) & $0 \%$ & $100 \%$ & $0 \%$ & $58 \%$ & $44 \%$ & $100 \%$ & 52.8 \\
& José Serra & $16 \%$ & $0 \%$ & $100 \%$ & $22 \%$ & $40 \%$ & $0 \%$ & 33.4 \\
& (PSDB) & & & & & & & \\
& Votes (MM) & 30.3 & 39.5 & 19.7 & 15.2 & 10.2 & .4 & 115.2 \\
\hline
\end{tabular}


Table 2 (continued)

\begin{tabular}{|c|c|c|c|c|c|c|c|c|}
\hline \multirow[t]{2}{*}{2006} & & \multicolumn{7}{|c|}{ From first round } \\
\hline & & Abstention & $\begin{array}{l}\text { Lula } \\
\text { (PT) }\end{array}$ & $\begin{array}{c}\text { Alckmin } \\
\text { (PSDB) }\end{array}$ & Heloisa & Cristovam & Others & $\begin{array}{l}\text { Votes } \\
\text { (MM) }\end{array}$ \\
\hline \multirow{4}{*}{$\begin{array}{l}\text { To second } \\
\text { round }\end{array}$} & Abstention & $97 \%$ & $0 \%$ & $2 \%$ & $6 \%$ & $43 \%$ & $0 \%$ & 30.0 \\
\hline & Lula (PT) & $3 \%$ & $100 \%$ & $10 \%$ & $74 \%$ & $57 \%$ & $100 \%$ & 58.3 \\
\hline & $\begin{array}{c}\text { Alckmin } \\
\text { (PSDB) }\end{array}$ & $0 \%$ & $0 \%$ & $88 \%$ & $19 \%$ & $1 \%$ & $0 \%$ & 37.5 \\
\hline & Votes (MM) & 29.9 & 46.6 & 40.0 & 6.6 & 2.5 & 0.3 & 125.8 \\
\hline \multirow[t]{2}{*}{2010} & & \multicolumn{7}{|c|}{ From first round } \\
\hline & & Abstention & $\begin{array}{l}\text { Dilma } \\
\text { (PT) }\end{array}$ & $\begin{array}{c}\text { José Serra } \\
\text { (PSDB) }\end{array}$ & $\begin{array}{l}\text { Maria } \\
\text { Silva }\end{array}$ & Plinio & Others & $\begin{array}{l}\text { Votes } \\
(\mathrm{MM})\end{array}$ \\
\hline \multirow{4}{*}{$\begin{array}{l}\text { To second } \\
\text { round }\end{array}$} & Abstention & $99 \%$ & $0 \%$ & $0 \%$ & $20 \%$ & $100 \%$ & $100 \%$ & 36.3 \\
\hline & $\operatorname{Dilma}(\mathrm{PT})$ & $0 \%$ & $100 \%$ & $0 \%$ & $28 \%$ & $0 \%$ & $0 \%$ & 55.8 \\
\hline & $\begin{array}{c}\text { José Serra } \\
\text { (PSDB) }\end{array}$ & $1 \%$ & $0 \%$ & $100 \%$ & $52 \%$ & $0 \%$ & $0 \%$ & 43.7 \\
\hline & Votes (MM) & 34.2 & 47.7 & 33.1 & 19.6 & 0.9 & 0.3 & 135.8 \\
\hline
\end{tabular}

A cross the three past elections, one can see that voters who abstained in the first round are unlikely to vote in the second; less than 5\% of those abstaining in the first round are likely to vote in the final election. Virtually all those who voted for the winner in the first round support the same candidate in the second round. Voters who supported the runner-up tend to do the same, although some may switch to the winner, as seen in the 2006 elections. In all three presidential elections immediately prior to the most recent one (2002, 2006 and 2010), the victory margin in the first round was smaller than the votes obtained by the eliminated candidates.

This pattern of results in the first round and vote transfer from the first to second rounds indicates that voters who can maintain their choice between the first and second round are likely to do so. Therefore the runner-up in the first round can only reverse the results in the final round if he or she is able to gather votes from candidates eliminated in the first round, especially the third-placed candidate. This was not possible in 2006 because, despite the fact that the margin of the winner over the runner-up was relatively small (6.6 million votes, out of 125.8 eligible voters), the eliminated candidates were more closely aligned with the winner in the first round; consequently, the eliminated candidates either supported the winner from the first round, or refrained from any political alliance in 2006.

Despite the much larger margin (of 14.6 million votes) in the first round of the 2010 elections compared to 2002 and 2006, the runner-up had a better chance to reverse the situation in the final round, because the third-place candidate was not politically aligned with the winner (in fact she had abandoned the winner's Workers' Party before running for president), and managed to gather 19.6 million votes in the first round. Therefore, the third-place candidate held the key for the final election results in 2010; if a large majority of her voters supported the runner-up, he would have been able to reverse the situation and win the final election. Unfortunately (for the runner-up), the third-place candidate (Marina Silva) did not support any of the two candidates for the second round in 2010; consequently, 28\% of her voters decided to abstain in the second round, and only 58\% shifted their vote to the runner-up, resulting in a strong mandate for the winner.

The results from the past three presidential elections discussed above provide valuable empirical generalizations to help plan future campaigns between the first and second rounds. First, they suggest a strong persistence in voter-choice among voters who have the option of maintaining their choice 
between the two rounds. Second, if the margin of votes between the winner and runner-up is smaller than the votes gathered by the other candidates, these eliminated candidates hold the key to victory for the surviving ones. Third, given that the eliminated candidates may hold the key to victory, the secondround campaign must focus on persuading their voters to shift their support. Fortunately, two-stage elections provide candidates with valuable hard data on voters' revealed preferences, via the vote counts within each electoral district, which can be used to plan and deploy the campaign strategy at the district level. This is my next focus, using the 2014 presidential elections in Brazil as an illustration.

\section{The 2014 Presidential Elections in Brazil}

Given the dynamics of vote-shifting between the first and second round in runoff elections as discussed earlier, my main purpose now is to leverage on the district-level results from the first round to plan the final political campaign, aiming at directing vote-shifting towards the desired outcome in the final round. For this purpose, I rely on a voter-choice model applied to the first-round results from the 2014 presidential elections in Brazil. Eleven candidates, supported by 32 political parties, competed in the first round on October 5, 2014. The winner and runner-up from this round competed in the final round three weeks later, on October 26, 2014.

As previously shown (Table 1), opinion polls indicated a close race between Aécio Neves (PSDB) and Marina Silva (PSB) for the second place and the chance to compete in the final round. However, the most direct and, some say, vicious attacks to Marina Silva came from the leading candidate, Dilma Rousseff (Castro, 2014; Furtado, 2014; UOL, 2014), who sought to deconstruct Marina's (a former member of Dilma's PT party) image as a candidate for the working class, a position already claimed by Dilma and her Workers' Party (PT). Dilma Rousseff and her PT party ran a generally aggressive campaign in the first round, also attempting to paint Aécio Neves as a member of the old dominant Brazilian oligarchy (Preite, 2014). Rather than directly fighting Marina Silva for second place, Aécio Neves focused his campaign towards the incumbent (Dilma), pointing to the looming recession, growing inflation and very public corruption scandals involving her government (Farina, 2014; Moura e Sousa, 2014).

\section{Results from the first round}

The last row of Table 3 summarizes the results of the first round of the 2014 elections, aggregated over all 6,266 electoral districts. The winner (Dilma - PT) had a large margin of more than 8 million votes over the runner up (Aécio - PSDB). However, the third-place candidate (Marina - PSB) attained 22 million votes, and therefore could be a spoiler in the final round, depending on how her voters decided to shift their choices when she was not a contender. 
Table 3

Parameter Estimates of the Voter-choice Model for the First Round of the 2014 Presidential Election in Brazil

\begin{tabular}{lccccccccc}
\hline Candidate & Intercept & $\begin{array}{c}\text { Factor } \\
\mathbf{1}\end{array}$ & $\begin{array}{c}\text { Factor } \\
\mathbf{2}\end{array}$ & $\begin{array}{c}\text { Factor } \\
\mathbf{3}\end{array}$ & $\begin{array}{c}\boldsymbol{\%} \text { under } \\
\mathbf{2 5}\end{array}$ & $\begin{array}{c}\boldsymbol{\%} \mathbf{6 0} \text { or } \\
\text { older }\end{array}$ & $\begin{array}{c}\text { HDI_ } \\
\text { Educ }\end{array}$ & $\begin{array}{c}\text { HDI- } \\
\text { Long }\end{array}$ & $\begin{array}{c}\text { HDI- } \\
\text { Income }\end{array}$ \\
\hline Abstention & 0.000 & $\mathbf{0 . 2 5 3}$ & $\mathbf{0 . 0 4 6}$ & $\mathbf{0 . 2 3 1}$ & 0.000 & 0.000 & 0.000 & 0.000 & 0.000 \\
Dilma & $\mathbf{1 . 1 0 3}$ & $\mathbf{- 0 . 2 8 0}$ & $\mathbf{0 . 2 6 6}$ & $\mathbf{0 . 1 1 7}$ & $\mathbf{0 . 6 8 7}$ & -0.100 & $\mathbf{0 . 1 8 7}$ & -0.011 & $\mathbf{- 0 . 3 9 8}$ \\
Aécio & $\mathbf{0 . 1 9 5}$ & $\mathbf{0 . 3 3 9}$ & $\mathbf{0 . 5 8 8}$ & $\mathbf{- 0 . 3 0 8}$ & $\mathbf{1 . 8 2 4}$ & $\mathbf{0 . 0 7 6}$ & $\mathbf{0 . 2 8 7}$ & $\mathbf{0 . 2 6 3}$ & -0.081 \\
Marina & 0.291 & $\mathbf{- 0 . 0 9 8}$ & $\mathbf{- 0 . 5 4 8}$ & $\mathbf{- 0 . 0 4 5}$ & $\mathbf{- 0 . 5 8 9}$ & $\mathbf{- 0 . 2 1 0}$ & $\mathbf{0 . 3 8 2}$ & $\mathbf{- 0 . 2 2 8}$ & 0.058 \\
Luciana & $\mathbf{- 2 . 0 9 0}$ & $\mathbf{- 0 . 0 8 9}$ & $\mathbf{- 0 . 0 8 1}$ & 0.000 & $\mathbf{- 4 . 7 1 8}$ & -0.060 & $\mathbf{0 . 4 4 0}$ & -0.008 & $\mathbf{0 . 3 0 8}$ \\
Pastor & $\mathbf{- 3 . 5 3 0}$ & -0.027 & $\mathbf{- 0 . 0 6 2}$ & 0.063 & $\mathbf{3 . 0 4 7}$ & $\mathbf{- 0 . 2 6 7}$ & $\mathbf{0 . 1 7 8}$ & 0.017 & 0.015 \\
Eduardo & $\mathbf{- 3 . 6 0 2}$ & $\mathbf{0 . 0 6 0}$ & 0.025 & $\mathbf{- 0 . 1 8 5}$ & $\mathbf{- 1 . 6 3 4}$ & 0.035 & $\mathbf{0 . 5 0 5}$ & $\mathbf{0 . 0 7 4}$ & $\mathbf{0 . 2 3 3}$ \\
Others (Right) & $\mathbf{- 3 . 8 2 6}$ & -0.017 & $\mathbf{- 0 . 1 6 5}$ & 0.036 & $\mathbf{0 . 5 4 1}$ & $\mathbf{- 0 . 2 2 6}$ & $\mathbf{0 . 4 0 3}$ & -0.026 & $\mathbf{0 . 1 4 9}$ \\
Others (Left) & $\mathbf{- 4 . 7 9 7}$ & $\mathbf{- 0 . 1 4 1}$ & $\mathbf{- 0 . 0 6 7}$ & $\mathbf{0 . 0 9 2}$ & -0.048 & -0.063 & $\mathbf{0 . 5 5 0}$ & $\mathbf{- 0 . 2 3 0}$ & 0.043 \\
Within-district & -- & $\mathbf{0 . 3 5 8}$ & $\mathbf{0 . 4 1 0}$ & $\mathbf{0 . 8 5 5}$ & -- & -- & -- & -- & -- \\
std. deviation & & & & & & & & & \\
Coefficient of & $\mathbf{0 . 4 5 1}$ & & & & & & & & \\
dissimilarity & & & & & & & & & \\
\hline
\end{tabular}

Note. Values in bold are statistically significant at the 0.01 level.

Most importantly, the results from the first round revealed substantial heterogeneity in voter preferences across districts suggesting that the campaign for the second round should be regionally targeted. The maps in Figure 1 show the geographic distribution for the margin of valid votes (proportion of votes for Dilma minus the proportion for Aécio) of the winner over the runner-up (panel A), the proportion of valid votes for the third-place candidate (panel B), proportion of abstentions (panel C) as well as the United Nations' Human Development Index (panel D). 


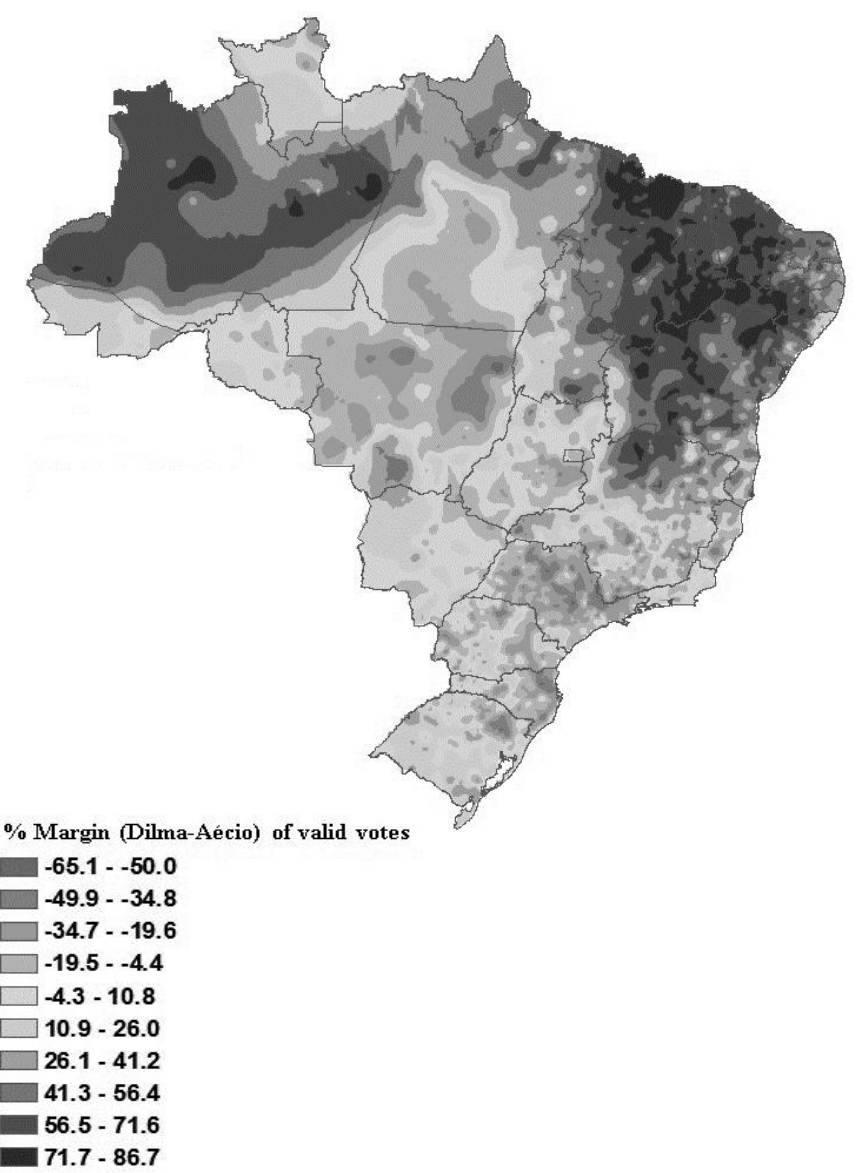

Panel A - Percentage margin of valid votes: Winner (Dilma) - Runner-up (Aécio)

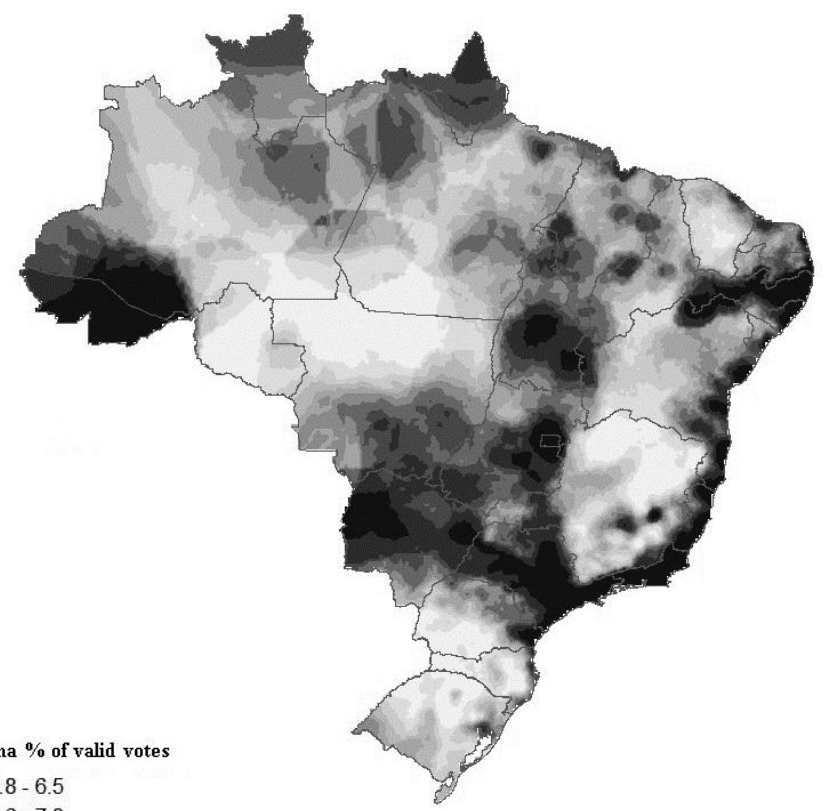

$$
\begin{aligned}
& \square 2.8-6.5 \\
& \square 6.6-7.8 \\
& \square 7.9-9.0 \\
& \square 9.1-10.1 \\
& \square 10.2-11.3 \\
& \square 11.4-12.6 \\
& 12.7-14.0 \\
& \square 14.1-15.4 \\
& \square 15.5-18.6 \\
& \square 18.7-61.0
\end{aligned}
$$

Panel B - Percentage of valid votes for the third-place candidate (Marina - PSB) 


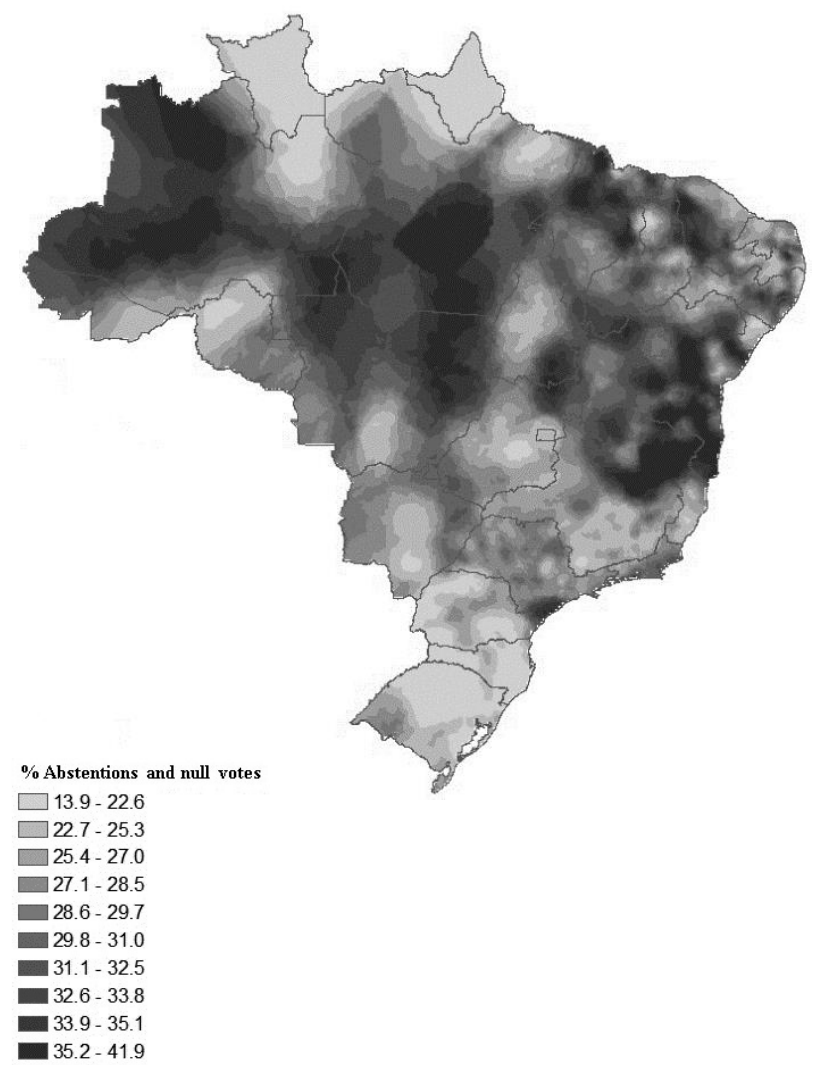

Panel C - Percentage of abstentions among all eligible voters

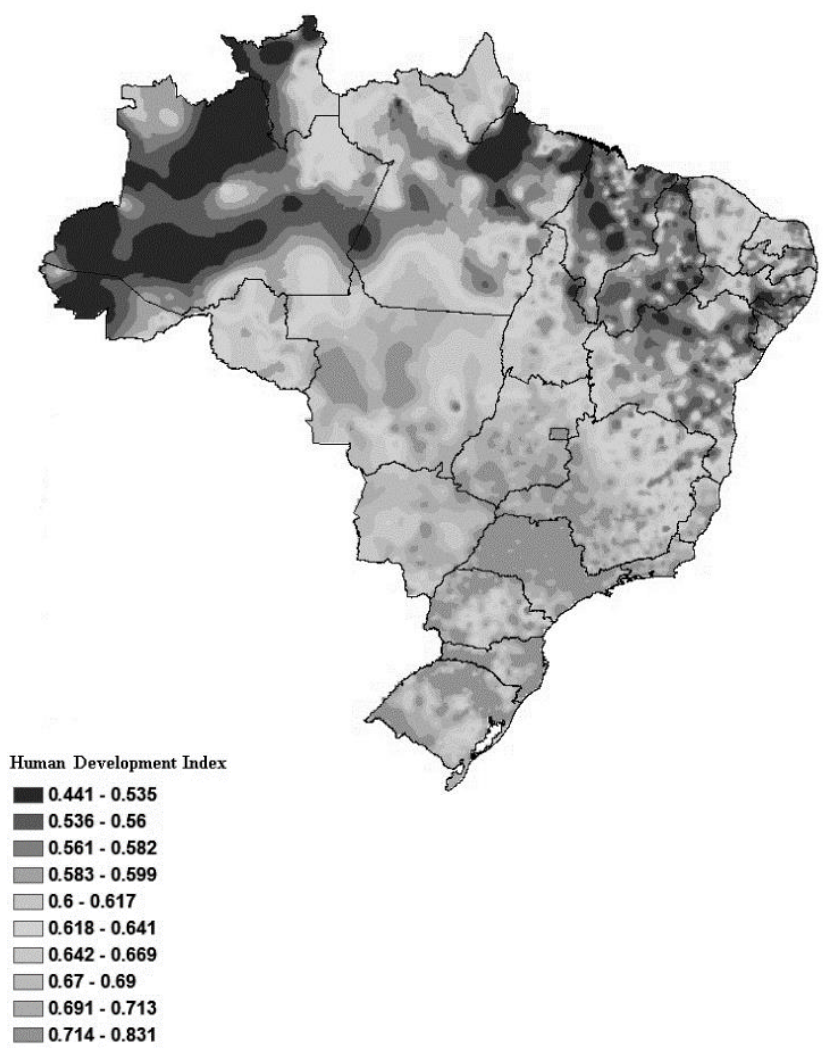

Panel D - United Nation's Human Development Index (2010)

Figure 1. Geographic Distribution of Votes and the Human Development Index Source: Produced by the author based on data from Programa das Nações Unidas para o Desenvolvimento. (n.d.). Ranking IDHM Municípios 2010. Retrieved from http://www.pnud.org.br/atlas/ranking/Ranking-IDHM-Municipios-2010.aspx 
A comparison of the margin by the winner (Dilma, the incumbent from the party that has held the presidency since 2002) over the runner-up (panel A) and the United Nations' HDI (panel D) suggests a strong support for the first-round winner in the less developed regions of Brazil. These regions have been the beneficiaries of a massive conditional cash-transfer program called Bolsa Familia (family grants), which by 2013 reached over 20 million of the poorest Brazilians (Campello \& Neri, 2013; Kamakura \& Mazzon, 2015). A comparison of abstentions (Panel C) and the HDI (panel D) also shows that the poor are more likely to abstain from voting than the rest of society. The geographic distribution for the third-place candidate (panel B) shows exactly where she can determine the final results of the 2014 presidential elections, and therefore, where her political capital is most valuable. Comparing this map with the one in Panel D one can see that support for the third-place candidate straddles socioeconomic strata.

\section{Modeling Voter Choice Behavior in the First Round}

Given the empirical generalizations from the three most recent elections (Table 2) and the results from the first round of 2014 (Figure 1), it became clear that the final results would depend on what the 26 million voters who chose one of the eliminated candidates (Marina Silva in particular) in the first round would do in the second round. Would they abstain, vote for the winner or the runner-up?

Fortunately, there is already an extensive body of knowledge on how to infer voter perceptions and preferences from observed voting behavior, stemming from the classical spatial theory by Black (1958) and Downs (1957), where candidates and voters are positioned on a common issues space with voters close to candidates they support. This spatial theory has been the basis for ideal-point voter-choice models (Enelow \& Hinich, 1984), which evolved into directional or vector models (Dow, 1998; MacDonald, Rabinowitz, \& Listhaug, 2001), although there is still some controversy on the relative merits of the two perspectives (Cho \& Endersby, 2003; Westholm, 1997, 2001). Either following the classic distance or directional perspective, voter-choice models are typically formulated as randomutility discrete-choice models (Train, 2003), commonly using a Multinomial Probit formulation (Lacy \& Burden, 1999; Quinn, Martin, \& Whitford, 1999; Schofield, Martin, Quinn, \& Whitford, 1998). A major advantage of the Multinomial Probit formulation over the simpler Multinomial Logit is the avoidance of the Independence from Irrelevant Alternative (IIA) property, which ignores potential similarities and closer substitution among certain candidates. However, some authors argue that the simplicity of the later formulation trumps the flexibility of the former for most applications (Dow \& Endersby, 2004). On the other hand, the IIA property becomes untenable when abstention is considered as one of the choice options, because it has characteristics that are distinct from the competing candidates. A compromise between the simple structure of the Multinomial Logit and the flexibility of the Multinomial Probit formulation is the Mixed Logit model (Glasgow, 2001; Train, 2003), which allows for heterogeneity in preference across voters, and consequently avoids the IIA property, despite following a Multinomial Logit formulation at the voter level. However, the Mixed Logit model still treats abstentions as another candidate, at the voter level, failing to capture their distinct nature.

Despite the developments in voter-choice modeling discussed above, uncovering voter perceptions and preferences revealed by the actual votes in the first round, aggregated within each electoral district, poses several challenges to the political analyst and marketer. First, votes are only observed at a minimum level of aggregation, within 6,266 districts (each containing 22,793 voters on average), which requires an individual voter-choice model that can be calibrated across groups of voters, rather than individuals, while accounting for the diversity in preferences within each district. Districtlevel modeling has been done via voter-share models (Katz \& King, 1999), which do not capture the unobserved heterogeneity in voter preferences neither within, or across districts. Second, there is a strong and obvious diversity of political preferences, as shown in Figure 1, demanding a voter-choice model that accounts for unobserved heterogeneity across districts (Glasgow, 2001; Rivers, 1988). Third, due to the fact that voting is aggregated within each district, and given that there is clear heterogeneity in political preferences across voters, one must account for the potential diversity of political preferences 
within each district. Otherwise, one would have to hold the unrealistic assumption that preferences vary across districts but are perfectly homogeneous within districts. Fourth, the results from the first round, summarized in Figure 1, clearly show a strong correlation between abstentions and relative preferences for the winner over the runner-up across districts, implying that abstentions cannot be modeled simply as another candidate, as in the common Multinomial Logit model (Dow \& Endersby, 2004). One must take into account the fact that the decision to abstain involves a choice between what the voter expects from the best available candidate, and the outside option, such as staying at home, going to work or to the beach (and later justifying the abstention from mandatory voting). Which cannot be addressed by a Mixed Logit formulation (Glasgow, 2001), because it occurs at the individual (voter) level. Finally, because my main purpose is to draw policy implications about the second-round of elections, the model must be parsimonious to produce estimates that are stable enough to offer projections out of the calibration data (first round). This is a situation where a Downsian perspective with candidates and districts positioned on a common space has great benefits, because the latent issues space serves as a space-reduction device leading to a parsimonious representation of the vote counts, depending on the number of dimensions selected to represent the Downsian issues space.

The voter-choice model proposed by Kamakura and Mazzon (2007) meets the requirements listed above. It relies on a latent-space reduction leading to a model that summarizes, with a few latent dimensions, the diversity of preferences across the 6,266 electoral districts. It utilizes a Nested-Logit formulation at the individual level, thereby assuming a structure where the decision to abstain involves an individual comparison between the best value the voter can expect from all candidates and the value of doing something other than going to the polls. This structure is essential for modeling a runoff election, because voters who supported an eliminated candidate do not have their best option available in the second round.

Therefore, the decision to vote or abstain will depend on the degree of similarity between the eliminated and surviving candidates. Most importantly, while it was developed as an individual voterchoice model, this model is calibrated on aggregate data. However, despite being applied to aggregate (district-level) data, the model still accounts for the unobservable diversity of political preferences within each district. I present the essential aspects of the voter-choice model below; details about the model and its estimation can be found elsewhere (Kamakura \& Mazzon, 2007). Following the voterchoice literature (Dow, 1998; Dow \& Endersby, 2004), I assume that the value or utility of candidate $j$ to voter $n$ in district $i\left(U_{j n(i)}\right)$ depends on observable characteristics of the district $\left(X_{n(i)}\right)$ and unobservable characteristics of the candidate $\left(\lambda_{j} Z_{n(i)}\right)$, as well as a stochastic component $\left(\varepsilon_{j n(i)}\right)$ :

$$
U_{j n(i)}=\alpha_{j}+\beta_{j} X_{n(i)}+\lambda_{j} Z_{n(i)}+\varepsilon_{j n(i)}
$$

where

- $\alpha_{j}=\quad$ candidate-specific intercept.

- $X_{n(i)}=\quad$ vector of demographic characteristics for voter $n$ 's electoral district $i$.

- $\beta_{j}=$ vector of demographic coefficients representing candidate $j$ 's appeal to a particular demographic constituency, relative to other candidates.

- $Z_{n(i)}=\quad \mathrm{p}$-dimensional vector of latent scores for district $i$ (to be estimated).

. $\lambda_{j}=\mathrm{p}$-dimensional vector of factor weights (or loadings) for candidate $j$.

- $\varepsilon_{j n(i)}=$ extreme-valued random error.

The second term on the right of equation 2 uses observed characteristics of a voter to explain the value of a candidate for that voter. However, because the characteristics of individual voters are not 
observable, the estimated coefficients $\beta_{j}$ for each candidate refer only to the aggregate characteristics of each district (one might argue that this demographic effect could be biased due to the endogenous targeting of political campaigns to specific demographic groups, but due to the difficulty in finding proper instruments to tease-out these endogenous effects for all 6,266 electoral districts, I leave this effort for future research). The third component $\left(\lambda_{j} Z_{n(i)}\right)$ accounts for unobservable "differences in voter preferences within voting districts, relative to the population average, by assuming that the $p$ dimensional latent scores $\left(Z_{n(i)}\right)$ are independently distributed within each district $i$ with a normal distribution $\mathrm{N}\left(\mu_{\mathrm{i}}, \sigma\right)$ " (Kamakura \& Mazzon, 2007, p. 70). Unobservable differences across districts are captured by the mean preferences for each $\operatorname{district}\left(\mu_{i}\right)$, which have standardized normal distributions across districts. This assumption results in standardized preference scores for each district in the issues space formed by the factor loadings $\left(\lambda_{j}\right)$, which define the positionof candidate $j$ in the same latent issuesspace.

Even though the "random errors $\varepsilon_{j n(i)}$ are independent, the random utilities $U_{j n(i)}$ are correlated across voters and candidates, and this correlation is captured by the factor structure $\left(\lambda_{j} Z_{n(i)}\right)$ " (Kamakura \& Mazzon, 2007, p. 70). Because of "this correlation of the random utilities, the" Kamakura and Mazzon (2007, p. 70) model avoids the Independence from Irrelevant Alternatives problem implicit in the popular multinomial Logit model (Cheng \& Long, 2007), so that

random utilities for candidates that are positioned closer to each other in the latent space will have higher correlations, thus accounting for the cannibalization of votes among similar candidates. If a voter $n(i)$ casts a ballot, the probability that he or she will vote for candidate $j$ is given by the (Kamakura \& Mazzon, 2007, p. 70).

well-known multinomial Logit formula (McFadden, 1974):

$$
P_{j n(i) \mid V}=\frac{e^{\alpha_{j}+\beta_{j} X_{i}+\lambda_{j} Z_{n(i)}}}{\sum_{j^{\prime}} e^{\alpha_{j^{\prime}}+\beta_{j^{\prime}} X_{i}+\lambda_{j^{\prime}} Z_{n(i)}}}
$$

In modeling the actual voting behavior in an election. The decision to vote is related, but not the same as the choice decision. The decision to cast a vote depends on the maximum utility the voter expects from all available candidates, compared to the utility associated with the outside option of doing something else other than going to the polls:

$$
P_{n(i) V}=\frac{e^{\delta W_{n(i)}}}{e^{V_{i o}}+e^{\delta W_{n(i)}}},
$$

where

. $\quad W_{n(i)}=\ln \left(\sum_{j=1}^{J} e^{\alpha_{j}+\beta_{j} X_{i}+\lambda_{j} Z_{n(i)}}\right)$ is the expected maximum utility to voter $n$ in district $i$ provided by all available candidates.

- $V_{n(i) o}$ the utility associated with abstaining from voting, defined as with any real candidate in (2), except that the intercept $\alpha_{o}$ and demographic coefficients $\beta_{o}$ are set to zero, and the factor loadings are set to $\lambda_{0}=-\sum_{j} \lambda_{j}$ for identification purposes. 
$\delta$ is the coefficient of dissimilarity; If $\delta=1$ the model reverts to a multinomial Logit model; If $\delta<1$, political candidates compete more closely with each other than with abstentions, so that elimination of candidates in the first round benefit surviving candidates more than abstentions.

When applied to actual voting data, voter-choice models must be fitted to aggregate data because actual voting data are available only at a certain level of aggregation, due to ballot inviolability. Fortunately, Kamakura and Mazzon (2007) demonstrated how to estimate the parameters of the individual voter-choice model, along with the factor scores for each district $\left(\hat{\mu}_{i}\right)$ using district-level vote counts as data, via simulated maximum-likelihood. Once the parameters of the model $(\hat{\Theta})$ and the factor scores $\left(\hat{\mu}_{i}\right)$ for each district $i$ are estimated using data from the first-stage election, the share of votes $\left(s_{i j}\right)$ for a remaining candidates $j$ in the second stage in district $i$ can be predicted via simulation by (Kamakura \& Mazzon, 2007),

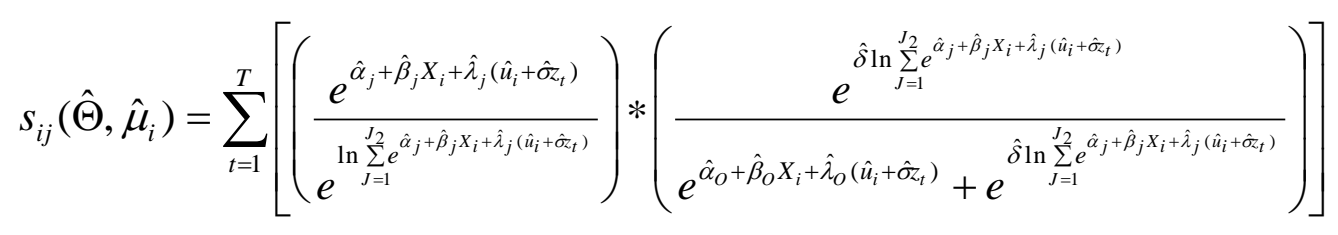

where $z_{t}(\mathrm{t}=1,2, \ldots, \mathrm{T})$ are $\mathrm{p}$-dimensional vectors of independent random draws from the standardized normal distribution.

I applied the model described above to the vote counts for the 6,266 electoral districts from the first round utilizing three latent factors (chosen based on the Bayesian Information Criterion) and five socio-demographic characteristics for each district:

1. \% under 25 - Proportion of the population under 25 years of age

2. $\% 60$ or older - Proportion of the population over 59 years of age

3. HDI(Educ) - United Nations' Human Development index based on the average years of schooling

4. HDI (Long) - United Nations' Human Development Index based on life expectation

5. HDI (Income) - United Nations' Human Development Index based on per capita income

Table 3 presents the parameter estimates from the model, setting Abstention as the baseline for identification purposes, and grouping the 5 less-relevant candidates into Others (Left) and Others (Right) categories. As expected, abstentions tend to be higher when the HDI is lower, with only a few exceptions; preferences for Marina and Others(Left) tend to be lower than for abstentions in highlongevity districts; preferences for Dilma tend to be lower than abstentions in high-income districts. The standard deviations for the latent scores within districts are all smaller than those across districts (set to 1 for identification purposes), indicating that preferences are more diverse across districts than within each district, as one would expect.

The estimates associated with the latent issues-space are better understood when mapped against each other, as shown in Figure 2. This latent-space is akin to the issue-space utilized in Downsian models of voter-choice (Black, 1958; Downs, 1957), except that this space is directly inferred from observed choices (Tomz \& Van Houweling, 2008), rather than measured via survey research (Cho \& Endersby, 2003; Dow, 1998). The top panel of Figure 2 shows the location of the 9 options available to voters, with minor candidates combined into two groups, each receiving less than 500,000 votes. Even though the model included an intercept to capture the large discrepancy in overall voter preferences (shown in Table 3), the less expressive options were clustered around the center of the latent space, indicating that there was less heterogeneity in preferences for these minor options across districts. The three-dimensional latent space is primarily defined by the top three candidates and abstention. 

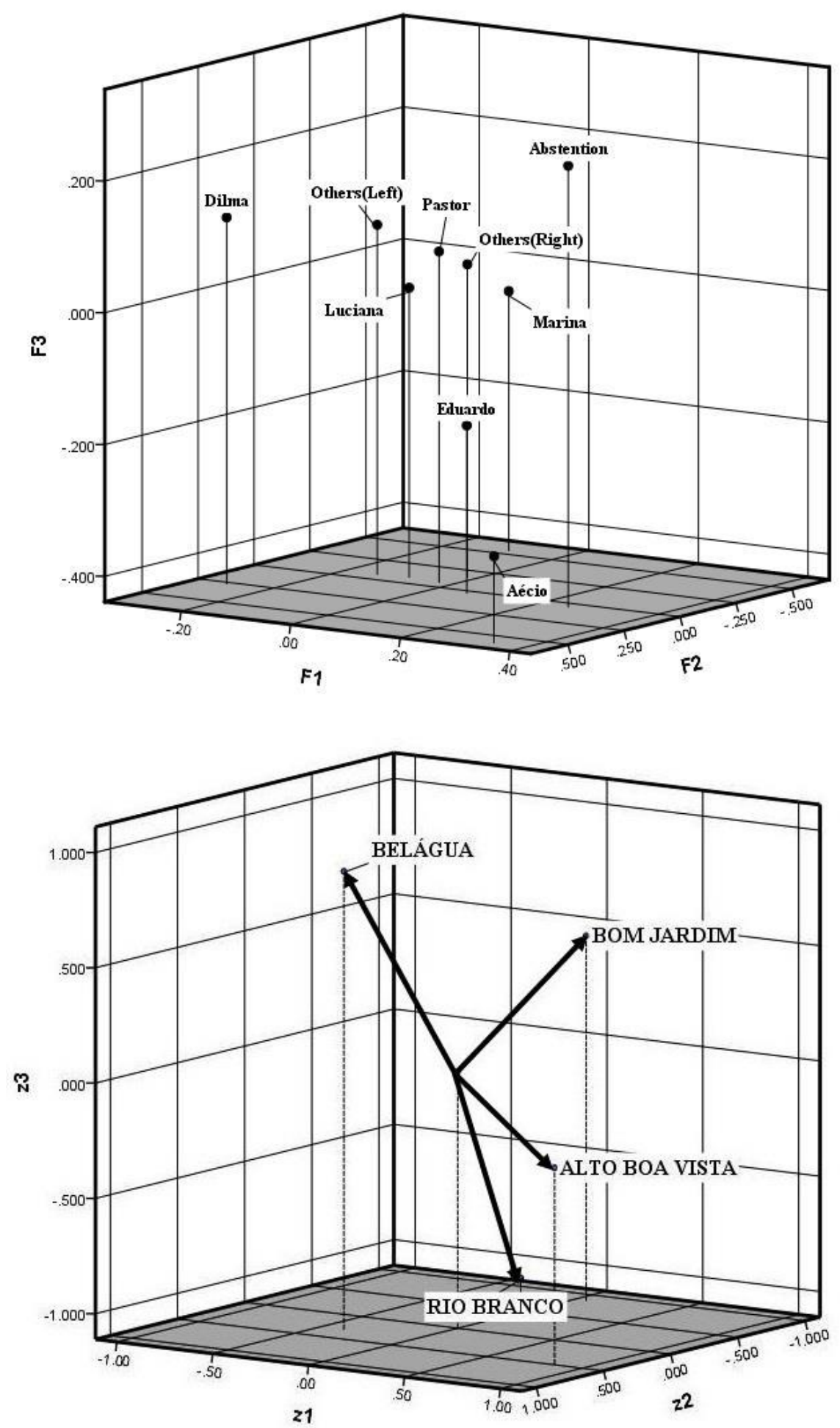

Figure 2. Latent Space of Candidates and Districts Estimated by the Voter-choice Model

Because it would be impossible to display all 6,266 districts in the bottom panel of Figure 2, I show only four, which best illustrate how the latent space can be helpful in planning the campaign for the second round. For example, the preference vector for the Belágua district clearly points in the direction of Dilma, reflecting her dominance in this district in the first round. Given the vote shifting observed in previous elections (Table 2), it was unlikely that results would change considerably in the second round of 2014. Similarly, the preference vector for Alto da Boa Vista points in the direction of Aécio, and therefore it is unlikely that his dominance in this district would be challenged in the second round of 2014. 
The real battle for votes should occur in districts like Bom Jardim and Rio Branco, where neither the winner nor the runner-up dominated in the first round. Rio Branco is a district where preferences revealed in the first round would suggest an advantage for Aécio in the second round, all else being equal. On the other hand, preferences revealed in the first round point to abstentions in Bom Jardim. However, the low coefficient of dissimilarity suggests that voters who went to the polls in the first round would have a tendency to come back in the second round, all else being equal. In other words, candidates are better substitutes for other candidates than for abstentions.

\section{Applying the voter-choice model to plan the campaign for the final round}

Given the parameter estimates reported in Table 3 and Figure 2, I applied equation 5, and some variants of it, for policy simulations. First, I produced predictions of vote counts for each of the 6,266 districts for the second round, under the assumption that the perceptions and preferences displayed in Table 3 and Figure 2 would remain the same in the second round of 2014. This scenario assumes that the surviving candidates would not be able to change hearts and minds in the short 3-week period before the second round. I then use the simulated votes for the second round to compute the Markov transition matrix described in Equation 1, to represent the vote shifting implied by the revealed preferences from the first round. This Markov transition matrix is shown in Table 4, with the observed first-round vote count in the last row, and the vote count projected for the second round (if the preferences from the first round would hold) in the last column.

Table 4

Markov Transition Matrix Implied by the Voter-choice Model Estimated from the First Round of 2014

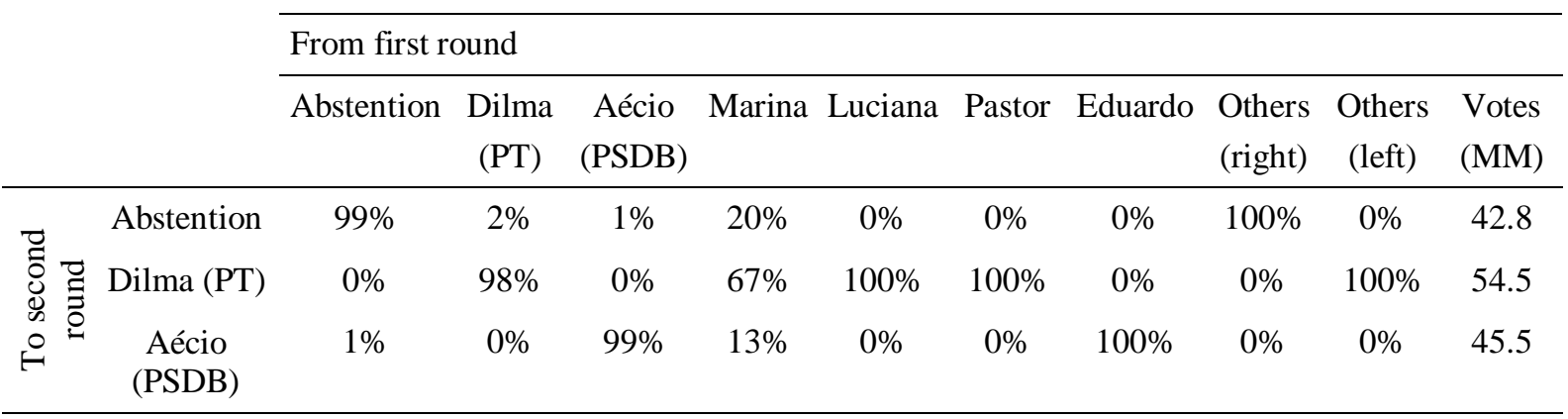

As in other recent elections (Table 2), it is clear that voters who abstained in the first round were unlikely to show up for the final voting in 2014. Similarly, voters who supported the winner and runnerup in the first-round were likely to continue to do so in the final election. One might argue that the two surviving candidates would attempt to reposition themselves in the direction with the highest density of voter preferences, given that all other competitors have been eliminated, leaving a substantial number of voters to be courted. However, with less than three weeks left before the final voting, it is unlikely that either candidate would be able to move from a position gained after a long and competitive campaign for the first round. The best the two candidates could hope is for political support from eliminated candidates, in an attempt to attract as many as possible of their original voters.

The simulation results in Table 4 strongly suggest that the status quo benefits the winner from the first round (Dilma). Unless bold action is taken by the runner-up (Aécio), the winner from the first round will prevail in the final election. Based on the preferences and perceptions revealed in the first round, $67 \%$ of the votes from the third-place candidate (Marina) would shift to the winner (Dilma), and only $13 \%$ would shift to the runner-up (Aécio), while $20 \%$ would not come back to the polls. It is clear that the runner-up must fight not only the winner but also abstentions, in order to reverse the results from the first round. Most importantly, the reversal of the runner-up's (Aécio) position would only be possible with a strong and explicit support from the third-place candidate (Marina). The value of any support offered by the other eliminated candidates is negligible, adding up to no more than three million votes, 
many already committed to a candidate, as shown in Table 4. Moreover, given the geographic distribution of votes shown in in Figure 1, it seems clear that the limited resources available to the runner-up in the limited time left before the final election must be targeted to the districts where he can hope to receive the most transfer of votes from the third-place candidate.

The support from the third-place candidate (Marina) to the runner-up (Aécio) did not become public until two weeks prior to the final election (UOL, 2014) through the release of a document in a joint meeting with the press (UOL, 2014) explaining how Aécio Neves' political positions agreed with Marina Silva's. This was not an easy argument to make, given that Marina's voters were naturally inclined to support the competitor (Dilma) in the second round, as indicated in Table 4. This political support translated into radio and TV spots aired during the 40 daily minutes of free airtime available to Aécio Neves, and interviews with the press.

Given the political scenario observed right after the first round, with the third-place candidate supporting the runner-up, I utilized the results from the first round to identify regions where this political alliance would be of greatest value for the runner-up. Figure 3 displays a map with the total number of voters for the third-place candidate (Marina) within a radius of 50km from each point in the map, thereby suggesting locations where Aécio Neves' campaign could deploy its limited resources to persuade Marina supporters to come back to the polls and vote for the runner-up (the campaign received more detailed tables and maps showing each electoral district). The main premise here was that supporters of the winner and runner-up are unlikely to change their minds (as indicated by Tables 2 and 4), and therefore the final election would be decided by those who supported the third-place candidate in the first round (because the votes attracted by the other eliminated candidates was negligible). As another measure suggesting locations where Aécio Neves' campaign could focus its efforts in the short period before the final election, I computed voter-potential as the product of the standard-deviation of the expected share of valid votes $\left(s_{i}\right)$ and the total number of expected voters in each district $\left(N_{i}\right)$, Voterpotential $=N_{i} \sqrt{s_{i}\left(1-s_{i}\right)}$.

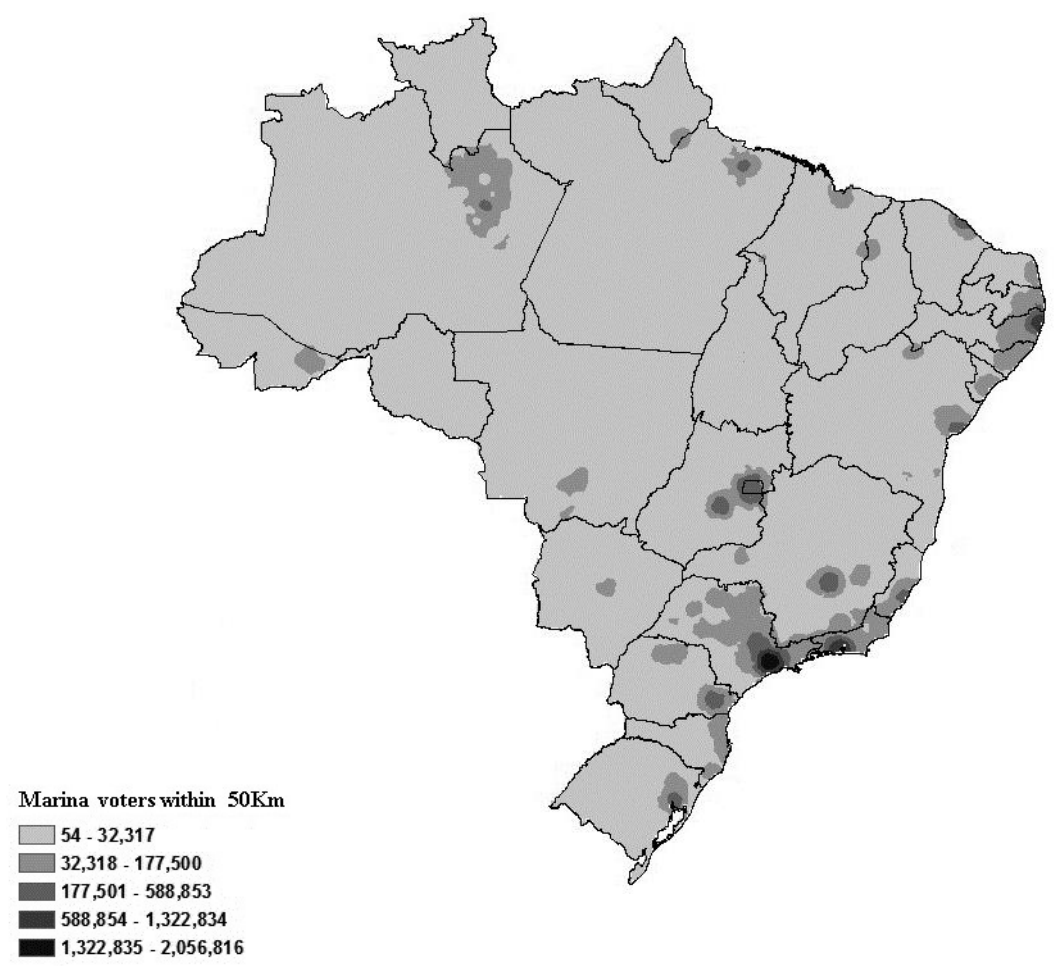

Figure 3. Number of Votes for the Third-place Candidate (Marina-PSB) Accumulated within 50Km from each Location

Figure 4 displays a map with the Voter-Potential accumulated within $50 \mathrm{Km}$ from each location in the map. This Voter-Potential measure indicates the number of votes that might be at play in each 
district, so that it tends to be smaller when one of the two competing candidates already has a commanding presence in the district (as expected from my voter-choice model). Therefore, Figure 4 indicates the regions where the runner-up has the best chances of gathering new voters and consequently, where his campaign should target its efforts, combining with the support from Marina in the regions shown in Figure 3. Figures 3 and 4 are very similar in this particular election because Marina accounted for almost all (86\%) of the remaining valid votes in the first round, once again making it clear that her voters would define the winner of the final election.

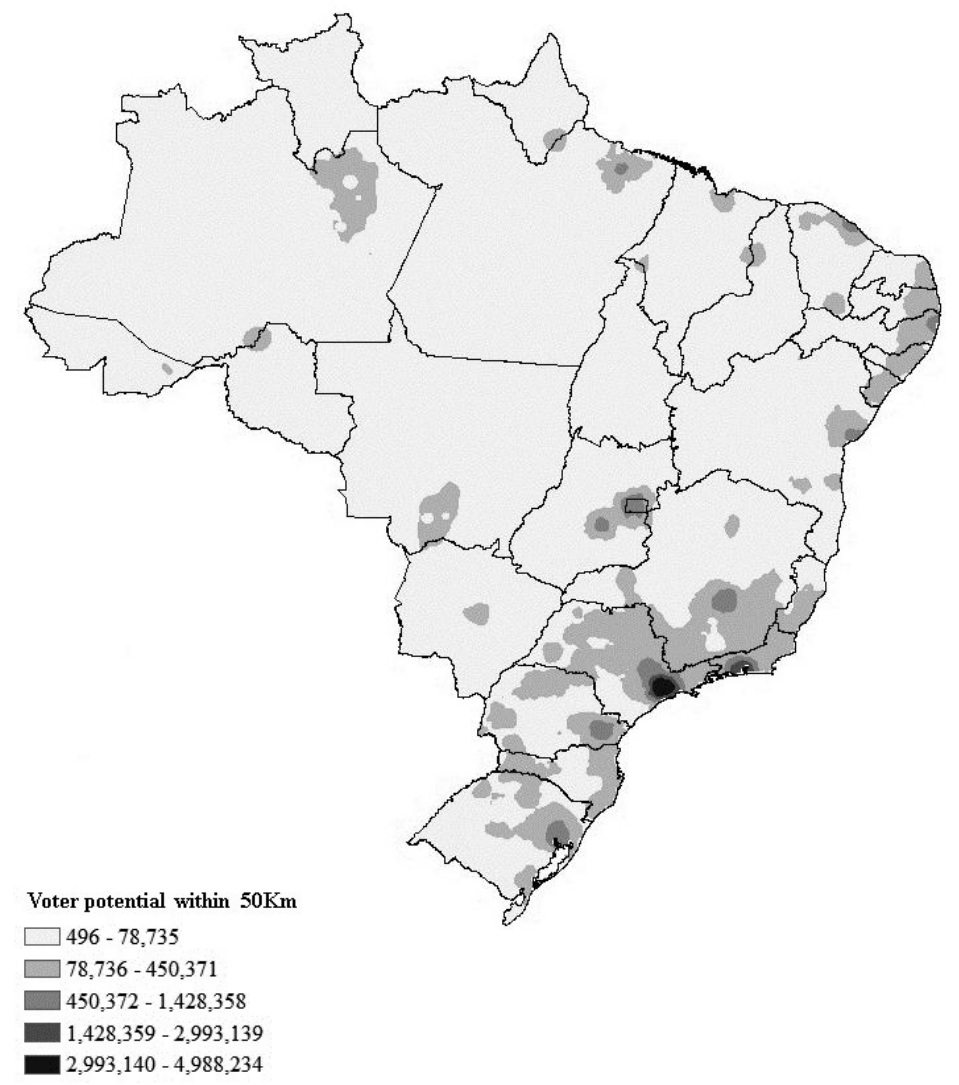

Figure 4. Voter-Potential Accumulated within 50Km from each Location

In order to demonstrate what was needed for the runner-up to win the final election, I modified the simulation equation (5) to consider various scenarios regarding the transfer of votes from the thirdplace candidate (Marina) to the candidate she supported for the final round (the runner-up, Aécio) and to abstentions. For this purpose, I use equation 5, but assume that the third-place candidate competes in the final round. I then simulate how the votes she would have attained (according to the model calibrated from the first round of votes) would transfer to the options actually available in the final round. I repeat these simulations under several scenarios defined by the proportion of abstentions among her supporters and by the proportion of valid votes transferred from her to the supported candidate (Aécio). Table 5 shows the expected outcomes from these simulations, measured as the percentage of valid votes expected for Aécio for different abstention rates and percentage of valid votes transferred in the second round, among those who voted for Marina Silva. 
Table 5

Expected Percentage of Final Valid Votes for Aécio Neves under Multiple Scenarios of VoteTransfer from Marina Silva

\begin{tabular}{|c|c|c|c|c|c|c|c|}
\hline & & \multicolumn{6}{|c|}{$\%$ of valid votes for Aécio in the second round among Marina voters } \\
\hline & & $50 \%$ & $\mathbf{5 5 \%}$ & $60 \%$ & $65 \%$ & $70 \%$ & $75 \%$ \\
\hline \multirow{4}{*}{$\begin{array}{l}\% \text { of abstention in } \\
\text { second round among } \\
\text { Marina voters }\end{array}$} & $\mathbf{0 \%}$ & $46.7 \%$ & $47.8 \%$ & $48.9 \%$ & $\mathbf{5 0 . 0 \%}$ & $51.1 \%$ & $52.3 \%$ \\
\hline & $5 \%$ & $46.6 \%$ & $47.7 \%$ & $48.7 \%$ & $49.8 \%$ & $50.9 \%$ & $51.9 \%$ \\
\hline & $10 \%$ & $46.5 \%$ & $47.6 \%$ & $48.6 \%$ & $49.6 \%$ & $50.6 \%$ & $51.6 \%$ \\
\hline & $15 \%$ & $46.5 \%$ & $47.5 \%$ & $48.4 \%$ & $49.4 \%$ & $50.4 \%$ & $51.3 \%$ \\
\hline
\end{tabular}

The simulation results shown in Table 5, combined with the evidence accumulated from the three previous presidential elections in Brazil, make it quite clear what Aécio Neves needed to win the final election. Past elections showed that voters tend to maintain the same option they chose in the first round, if it is still available (see Table 2). Therefore, in order to win, Aécio Neves needed to attract a large proportion of Marina Silva's votes. First, he needed to persuade these voters to come back to the polls (thereby competing against abstentions). Moreover, he needed to ensure these voters would transfer their preferences from Marina Silva to him.

The empirical evidence offered by opinion polls suggested that victory was a possibility for Aécio Neves. According to voter intentions reported by Brazil's best-known pollster Datafolha less than two weeks before the final election (reports \# PO813771, PO813773 and PO813776), 14\% to 16\% of Marina voters would abstain or were undecided for the second round, and between $71 \%$ and $79 \%$ of Marina voters casting a ballot in the second round would vote for Aécio. As shown in my policy simulations (Table 4), if $15 \%$ of Marina voters decided to abstain in the second round, Aécio Neves would need at least $70 \%$ of all the valid votes from these voters to win the final election. Therefore, these prognostics would imply a narrow victory for Aécio Neves, if any.

\section{Post mortem}

Unfortunately, opinion polls proved to be as unreliable in the final round of the 2014 election as they were in the first round. The winner from the first round (Dilma Rousseff) also won the final round, albeit with a smaller margin of valid votes. Table 6 shows the transition matrix estimated from the actual vote counts in the first and second rounds of the 2014 presidential elections (from the Markov model in Equation 1). These results suggest that the support from Marina Silva was enough to reverse the natural tendency for her voters to abstain or to switch to Dilma Rousseff (as shown in Table 4). However, this reversal did not reach the level of vote-shifting required for Aécio Neves to win.

Table 6

Estimated Markov Transition Matrix from the 2014 Presidential Elections in Brazil

\begin{tabular}{|c|c|c|c|c|c|c|c|c|c|c|c|}
\hline & \multicolumn{10}{|c|}{ From first round } \\
\hline & & Abstention & Dilma & Aécio & Marina & Luciana & Pastor & Eduardo & $\begin{array}{l}\text { Others } \\
\text { (right) }\end{array}$ & $\begin{array}{l}\text { Others } \\
\text { (left) }\end{array}$ & $\begin{array}{l}\text { Votes } \\
\text { (MM) }\end{array}$ \\
\hline \multirow{4}{*}{ 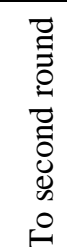 } & Abstention & $97 \%$ & $2 \%$ & $0 \%$ & $2 \%$ & $0 \%$ & $0 \%$ & $0 \%$ & $0 \%$ & $0 \%$ & 37.3 \\
\hline & Dilma & $0 \%$ & $98 \%$ & $0 \%$ & $44 \%$ & $9 \%$ & $100 \%$ & $0 \%$ & $0 \%$ & $100 \%$ & 54.5 \\
\hline & Aécio & $3 \%$ & $0 \%$ & $100 \%$ & $54 \%$ & $91 \%$ & $0 \%$ & $100 \%$ & $100 \%$ & $0 \%$ & 51.0 \\
\hline & Votes (MM) & 38.8 & 43.3 & 34.9 & 22.2 & 1.6 & 0.8 & 0.6 & 1.5 & 0.2 & 142.8 \\
\hline
\end{tabular}


The Markov transition matrix in Table 6 shows quite clearly why Aécio Neves failed to reverse the results from the first round. It also shows how misleading the prognostics provided by opinion polls prior to the final round were (as they also were performed prior to the first round). Aécio Neves was able to secure about 55\% of the valid votes from Marina Silva's voters. This was much less than then $71 \%$ to $79 \%$ predicted by intention polls. Most importantly, as we anticipated from the simulations shown in Table 4, this was less than he needed to win the final election.

\section{Conclusions}

My experience analyzing the results from the four recent two-stage presidential elections in Brazil suggests that the political campaign for the final round should be distinct from the first. One of the main reasons for this distinction is that before the first round, the political analyst and marketer can only rely on stated preferences, gathered via surveys from a relatively small sample of voters. As shown in Table 1 , the empirical evidence from the most recent election is that these voter-intention polls might be able to predict the winner, but are particularly poor in quantifying the margin of victory. Predicting the winner of the first round is not necessarily the most valuable piece of intelligence sought by the political analyst and campaigner; they need to know the micro-geographic areas where their candidate has strengths and weaknesses, something the political polls in Brazil were not able to provide, given the limited sample at the regional (electoral district) level.

In contrast, campaign planners for the second round can rely on preferences revealed through actual voter behavior, albeit aggregated at the district level (each containing 22,793 voters on average), which are a much more accurate and reliable source of data on voters' preferences at the first round than voter-intention polls. Most importantly, this information is available for each of the 6,266 districts, providing valuable localized information to help the campaigner deploy limited resources in a short time, in a more regionally-focused fashion, something opinion polls rarely offer.

Of course, the value of preferences revealed in the first round for planning the final campaign depends on how stable voter preferences will remain in the three weeks between the two rounds. One might argue that candidates would benefit considerably from repositioning themselves in the hearts and minds of voters once all other candidates are eliminated in the first round. However, the hard-earned image attained by the two surviving candidates during a much longer and competitive campaign for the first round is unlikely to change considerably during a much shorter campaign of less than three weeks before the final voting. Nevertheless, I demonstrated how these revealed preferences can play an important role in planning the final campaign, because at the very least, they provide a benchmark of what will happen if nothing is done to change voters' perceptions and preferences. After all, the most valuable information during the campaign is not who is expected to win, but what can be done by each campaign to ensure the desired outcome. Beyond this baseline, I demonstrated how the voter-choice model can be used for policy simulations for the second round, helping the political analyst and campaigner understand what will be needed to improve the chances of victory for their candidate at each electoral district.

The actual vote counts from the first round only reveal preferences and the relative position of candidates and districts at the moment of the first election. They may reveal where the two competing candidates are strong/weak, and how voters for the eliminated candidates may shift their votes in the final election if their perceptions and preferences don't change. However, they do not provide any insight into why these strengths and weaknesses exist or what the candidates can do to change voter perceptions and preferences. Voter-intention polls and opinion surveys are still important in the final campaign, to provide candidates with these qualitative insights. However, the focus of these surveys and voter-intention polls must be different from the first round.

Their samples must be stratified to oversample voters for the eliminated candidates because, as shown in the past four presidential elections I analyzed, these voters are likely to decide the final results; 
voters who supported the two surviving candidates in the first round, or who did not come to the polls are unlikely to change their choice. Pollsters must oversample the voters for eliminated candidates, not only because of their crucial role in the final election, but also because typically, they represent a minority in the population of voters. For the second round, the focus should be on how these particular voters see the surviving candidates as substitutes for their favorite (eliminated) one, and whether they believe in the political endorsement made by their favorite candidate. Will they abstain? Will they support the winner, or runner-up from the first round? These are the most critical questions for the political analyst and campaigner in the second round.

Moreover, while I illustrate how a voter-choice model can be applied to plan the second-round campaign in a two-stage presidential election, the same model and principles can be applied in other two-stage elections (state governor, state legislator, etc.), as long as the required micro-level (electoral district) data are available (Kamakura \& Mazzon, 2007).

Finally, my analysis of the two rounds in the past four presidential elections carries some caveats; my Markov analysis of voting transitions from the first to the second round ignored the (distinct) possibility of voter heterogeneity within each district. I chose to use the traditional Markov model because this simple model fits surprisingly well across a fairly large population of voting districts, leaving little room for improvement with a less parsimonious ecological inference model. Moreover, some of the voter heterogeneity is already accounted in these Markov transitions, because these transitions are conditional on observed preferences in the first round. While the potential for aggregation bias might exist in the Markov analysis of past elections, this bias is avoided in my analysis of the 2014 election, because the Kamakura and Mazzon (2007) model accounts for unobserved heterogeneity both within and across districts.

\section{References}

ACE - The Electoral Knowledge Network. (n.d.). Comparative data. Retrieved from http://aceproject.org/epic-en?question=ES003\&f=d

Black, D. (1958). The theory of committees and elections. New York: Cambridge University Press.

Brown, P. J., \& Payne, C. D. (1986). Aggregate data, ecological inference and voting transitions. Journal of the American Statistical Association, 81(394), 452-460. http://dx.doi.org/10.2307/2289235

Campello, T., \& Neri, M. C. (2013). Programa Bolsa Família: uma década de inclusão e cidadania. Brasília, DF: IPEA.

Castro, G. (2014, agosto 31). Dilma defende protecionismo na indústria e ataca Marina. Veja.com. Retrieved from http://veja.abril.com.br/politica/dilma-defende-protecionismo-na-industria-eataca-marina/

Cheng, S., \& Long, J. S. (2007). Testing for IIA in the multinomial logit model. Sociological Methods \& Research, 35(4), 583-600. http://dx.doi.org/10.1177/0049124106292361

Cho, S., \& Endersby, J. W. (2003). Issues, the spatial theory of voting, and British general elections: a comparison of proximity and directional models. Public Choice, 114(3), 275-293. http://dx.doi.org/10.1023/A:1022616323373

Dow, J. K. (1998). Directional and proximity models of voter choice in recent US presidential elections. Public Choice, 96(3), 259-270. http://dx.doi.org/10.1023/A:1004958100196

Dow, J. K., \& Endersby, J. W. (2004). Multinomial probit and multinomial logit: a comparison of choice models for voting research. Electoral Studies, 23(1), 107-122. http://dx.doi.org/10.1016/S02613794(03)00040-4 
Downs, A. (1957). An economic theory of democracy. New York: Harper \& Row.

Enelow, J. M., \& Hinich, M. J. (1984). The spatial theory of voting. New York: Cambridge University Press.

Farina, C. (2014, setembro 23). Aécio ataca 'intervencionismo absurdo' de Dilma e alfineta Marina. Veja.com. Retrieved from http://veja.abril.com.br/politica/aecio-ataca-intervencionismoabsurdo-de-dilma-e-alfineta-marina/

Furtado, V. (2014, setembro 11). Dilma ataca Marina: 'não somos do tipo que muda de lado. Temos carácter'. $O$ Globo. Retrieved from http://oglobo.globo.com/brasil/dilma-ataca-marina-naosomos-do-tipo-que-muda-de-lado-temos-carater-13899969

Glasgow, G. (2001). Mixed logit models for multiparty elections. Political Analysis, 9(2), 116-136.

Golder, M. (2005). Democratic electoral systems around the world, 1946-2000. Electoral Studies, 24(1), 103-121. http://dx.doi.org/10.1016/j.electstud.2004.02.008

Hillygus, D. S. (2005). Campaign effects and the dynamics of turnout intention in election 2000. The Journal of Politics, 67(1), 50-68. http://dx.doi.org/10.1111/j.1468-2508.2005.00307.x

Instituto de Pesquisa Datafolha. (2014, September 19). Brasil eleições 2014, intenções de votos para presidência da República (Relatório $\mathrm{n}^{\circ}$ PO813761). Retrieved from http://media.folha.uol.com.br/datafolha/2014/09/19/intencao_de_voto_presidente.pdf

Instituto de Pesquisa Datafolha. (2014, September 26). Brasil eleições 2014, intenções de votos para presidência da República (Relatório $\mathrm{n}^{\circ}$ PO813763). Retrieved from http://media.folha.uol.com.br/datafolha/2014/09/27/intencaodevotoeavaliacaopresidente.pdf

Instituto de Pesquisa Datafolha. (2014, October 4). Brasil eleições 2014, intenções de votos para presidência da República (Relatório $\mathrm{n}^{\circ} \quad$ PO813765). Retrieved from http://media.folha.uol.com.br/datafolha/2014/10/04/intencao_de_voto_presidente.pdf

Instituto de Pesquisa Datafolha. (2014, October 16). Brasil eleições 2014, intenções de votos para presidência da República- $2^{o}$ turno (Relatório $\mathrm{n}^{\circ}$ PO813773). Retrieved from http://media.folha.uol.com.br/datafolha/2014/10/15/intencao-de-voto-presidente-2-turno.pdf

Instituto de Pesquisa Datafolha. (2014, October 22). Brasil eleições 2014, intenções de votos para presidência da República $-2^{o}$ turno (Relatório $\mathrm{n}^{\circ}$ PO813775). Retrieved from http://media.folha.uol.com.br/datafolha/2014/10/22/intencao_de_voto_presidente_2_turno.pdf

Instituto de Pesquisa Datafolha. (2014 October 24). Brasil eleições 2014, intenções de votos para presidência da República - $2^{o}$ turno (Relatório $\mathrm{n}^{\circ}$ PO813776). Retrieved from http://media.folha.uol.com.br/datafolha/2014/10/25/intencao_de_voto_presidente_vespera_2_tu rno.pdf

Kamakura, W. A., \& Mazzon, J. A. (2007). Accounting for voter heterogeneity within and across districts with a factor-analytic voter-choice model. Political Analysis, 15(1), 67-84. http://dx.doi.org/10.1093/pan/mpl006

Kamakura, W. A., \& Mazzon, J. A. (2015). Measuring the impact of a conditional cash transfer program on consumption behavior with propensity scoring. Customer Needs and Solutions, 2(3), 302-316. http://dx.doi.org/10.1007/s40547-015-0037-0

Katz, J. N., \& King, G. (1999). A statistical model for multiparty electoral data. The American Political Science Review, 93(1), 15-32. 
Lacy, D., \& Burden, B. (1999). The vote-stealing and turnout effects of Ross Perot in the 1992 U.S. presidential election. American Journal of Political Science, 43(1), 233-255. http://dx.doi.org/10.2307/2991792

MacDonald, S. E., Rabinowitz, G., \& Listhaug, O. (2001). Sophistry versus science: on further efforts to rehabilitate the proximity model. Journal of Politics, 63(2), 482-500. http://dx.doi.org/10.1111/0022-3816.00075

McCarthy, C., \& Ryan, T. M. (1977). Estimates of voter transition probabilities from the British general elections of 1974. Journal of the Royal Statistical Society Series A, 140(1), 78-85. http://dx.doi.org/10.2307/2344518

McFadden, D. (1974). Conditional logit analysis of qualitative choice behavior. In P. Zarembka (Ed.), Frontier in econometrics (pp. 105-142). New York: Academic Press.

Moura e Sousa, M. de, (2014, setembro 4). Aécio ataca Dilma e Marina e tenta recuperar terreno em Minas Gerais. Valor Econômico. Retrieved from http://www.valor.com.br/eleicoes2014/3683156/aecio-ataca-dilma-e-marina-e-tenta-recuperarterreno-em-minas-gerais

Pérez-Linãn, A. (2006). Evaluating presidential runoff elections. Electoral Studies, 25(2), 129-146. http://dx.doi.org/10.1016/j.electstud.2005.04.002

Preite, W, Sobrinho (2014, setembro 15). Marina ataca Lula: 'estou fazendo debate com Dilma e Aécio, não com auxiliares'. Último Segundo. Retrieved from http://ultimosegundo.ig.com.br/politica/2014-09-15/marina-ataca-lula-estou-fazendo-debatecom-dilma-e-aecio-nao-com-auxiliares.html

Programa das Nações Unidas para o Desenvolvimento. (n.d.). Ranking IDHM Municípios 2010. Retrieved from http://www.pnud.org.br/atlas/ranking/Ranking-IDHM-Municipios-2010.aspx

Quinn, K. M., Martin, A. D., \& Whitford, A. B. (1999). Voter choice in a multi-party democracy: a test of competing theories and models. American Journal of Political Science, 43(4), 1231-1247. http://dx.doi.org/10.2307/2991825

Rivers, D. (1988). Heterogeneity in models of electoral choice. American Journal of Political Science, 32(3), 737-757. http://dx.doi.org/10.2307/2111244

Schofield, N., Martin, A. D., Quinn, K. M., \& Whitford, A. B. (1998). Multiparty electoral competition in the Netherlands and Germany: a model based on multinomial probit. Public Choice, 97(3), 257-293. http://dx.doi.org/10.1023/A:1005025522565

Tomz, M., \& Van Houweling, R. P. (2008). Candidate positioning and voter choice. American Political Science and Review, 102(3), 303-318. http://dx.doi.org/10.1017/S000712340400002X

Train, K. (2003). Discrete choice methods with simulation. Cambridge, UK: Cambridge Press.

UOL. (2014, setembro 1). Dilma ataca e questiona Marina sobre orçamento para executar promessas. Retrieved 27 January, 2015, from http://eleicoes.uol.com.br/2014/noticias/2014/09/01/dilmaabre-debate-em-ataque-contra-marina.htm

Westholm, A. (1997). Distance versus direction: the illusory defeat of the proximity theory of electoral choice. American Political Science Review, 91(4), 865-883. http://dx.doi.org/10.2307/2952170

Westholm, A. (2001). On the return of epycicles: some crossroads in spatial modeling revisited. Journal of Politics, 63(2), 436-481. http://dx.doi.org/10.1111/0022-3816.00074 


\section{Author Profile}

Wagner Antonio Kamakura

6100 Main Street MS531, 77005-1892, Houston, Texas, United States. E-mail: kamakura@ rice.edu 